\title{
Micro RNAs: an arguable appraisal in medicine
}

\author{
Voglova K, Bezakova J, Herichova I \\ Department of Animal Physiology and Ethology, Faculty of Natural Sciences, \\ Comenius University Bratislava, Slovak Republic \\ E-mail: herichova@fns.uniba.sk
}

\begin{abstract}
Micro RNAs (miRNAs) represent a newly discovered class of regulatory molecules in the human body. miRNA is a short double stranded RNA sequence interfering with mRNA, causing in most cases, inhibition of translation. Synthesis of miRNAs shows an increasing developmental pattern and postnatally miRNAs are synthesized in all cells possessing transcriptional machinery. miRNAs usually target several mRNAs and therefore conclusive evidences proving their functions are not always ease to be acquired. In spite of this difficulty, functions of miRNAs were firmly established in the development, the cardiovascular and neural diseases, and cancer. Many miRNAs have been reported to be associated with physiological state of cells and/or tissues. This finding becomes fundamental, especially when consider that these miRNAs can be released from cell into intracellular space or circulation. Correlation between miRNA production in tissues and its contribution to multisource miRNA pool in the circulation is in a focus of biomarker-oriented researchers. Recently, circulating miRNAs have been suggested to be applicable as biomarkers in several types of cancer, cardiovascular injury, and diabetes. Role of miRNAs in the organism intercellular signaling is still under the broad investigation. Several miRNA mimics, intended for treatment of disease, are being currently tested in the clinical trials.
\end{abstract}

Key words: biomarkers, exosome, therapeutics, development, cancer, cardiovascular, neural

Micro RNAs (miRNAs) are small ( 17-25 nt) regulatory molecules involved in regulation of gene expression. Impact of miRNA on transcriptome seems to be enormous and therefore, miRNAs have recently appeared in the centre of biomedically oriented research. Mature miRNAs are synthesized from precursor molecules with use of complex created by Drosha and DGCR8 (DiGeorge syndrome critical region gene 8) executing its function in the nucleus followed by Dicer cleavage in the cytoplasm (reviewed in Zhang et al. 2008; Deng et al. 2014). miRNAs execute their function in the cytoplasm after loading into RISC (RNA-induced silencing complex) complex, containing Argonaute proteins that guides leading strand of miRNA duplex to complementary sequence of mRNA. miRNA usually inhibits expression of several target mRNAs.

Functions of miRNAs have been demonstrated in several physiological processes and they are believed to be implicated in many pathologies. It has been shown that miRNAs levels in the circulation frequently reflect physiological status of the cell and/ or organ. Thanks to high miRNAs stability in plasma and serum, they show high potential to be employed as biomarkers (Reid et al. 2011). Recent review provides a short overview of proved medically relevant miRNA/mRNA interactions. Knowledge about these interactions, in some cases, has been used in translational medicine, oriented on biomarker research and miRNA based therapeutics.

Corresponding author: Iveta Herichova, PhD., Department of Animal Physiology and Ethology, Faculty of Natural Sciences, Comenius University in Bratislava, Ilkovicova 6, 84215 Bratislava, Slovak Republic; phone: 00421-2-60296572; 


\section{Proved miRNA-targets interac- tions important in human}

There are several effective means (Kiriakidou et al. 2004) for identification of miRNAs targets. The search is based on knowledge about mammalian genomes available in public databases (e.g. TargetScan, PicTar, Miranda). Thanks to in silico tools availability for analysis of miRNA targets, a huge number of candidates for miRNA/mRNA interactions have emerged. Only a small proportion of them is firmly proved to be physiologically relevant. Many examples of miRNA/mRNA medically relevant interactions are provided in the next paragraph. Table 1 lists predominantly examples with strong experimental evidence. This part of miRNA research field provides still a lot of space for experimental effort and it will be undoubtedly very fruitful in the near future.

\section{Role of miRNA in development}

lin- 4 was the first miRNA discovered and together with lin-7 belongs to the best-studied miRNAs. They have been shown to act in a heterochronic pathway to regulate developmental timing in Caenorhabditis elegans (Lee et al. 1993; Wightman et al. 1993; Reinhart et al. 2000). Loss of their function results in a retarded development (Lee et al. 1993). lin-4 controls worm development at an earlier (Lee et al. 1993) and let-7 at a later stage (Reinhart et al. 2000).

miRNAs can functioning as regulators of animal development at various tissues under different developmental stages (Zhang et al. 2007a). Some of the miRNAs, identified in mouse (also conserved in human), seems to be highly tissue specific a thus may play a crucial role in the tissue differentiation and cell lineage decisions. miRNAs are essential for the normal development of various animal tissues (Lagos-Quintana et al. 2002), including stem cells (Kanellopoulou et al. 2005), embryo (Kanellopoulou et al. 2005), brain (Schratt et al. 2006), heart (LagosQuintana et al. 2002), limb (Harfe et al. 2005), liver, and others (Lagos-Quintana et al. 2002). miRNAs have been identified to play a critical role in the fundamental brain developmental processes, e.g. neuronal differentiation. Neurodevelopmental and neural differentiation processes, occurring at various stages of life, can be compromised by disrupted miRNAs biogenesis (Szafranski et al. 2015).

Specific role of miRNA in mammalian development is well supported. Several miRNAs have been reported to play a role in the regulation of stem cells and development of nervous system. miR-9 together with miR-124 and miR-125b appear to be associated with induction of human pluripotent stem cells differentiating into neurons (Roese-Koerner et al. 2013). Role of miR-124 in development of nervous system has been confirmed by Makeyev et al. (2007) showing that miR-124 may participate in the differentiation of progenitor cells to mature neurons by regulating neuron-specific alternative splicing.

miRNAs are important in immune system development, function, and response. They can facilitate the cell fate decision of immune cells, regulate the central elements of adaptive immune response, and affect the viral replication (Pedersen and David 2008). It has been revealed that a number of miRNAs (e.g. miR-21, miR-29, miR-31, miR-155, miR-223, and many others) participate in the bone homeostasis including bone resorption, regulation of osteoclast differentiation, and osteoporosis (Tang et al. 2014). miR-150 can drive differentiation of megakaryocyteerythrocyte progenitors into megakaryocytes at the expense of erythroid cells in vitro and in vivo (Lu et al. 2008).

In spite of miRNA importance during development, only very few miRNAs are expressed and effective in early embryo (Thomson et al. 2006).

\section{miRNA and cancer}

Low abundance of miRNAs in the early embryonic cells resembles cell ongoing oncologic malformations, where miRNA synthesis is often down-regulated (Thomson et al. 2006; Mogilyansky and Rigoutsos 2013). This is in accordance with the reduced Dicer expression, observed in fraction of patients with lung cancer and significantly altered Dicer expression prognostic impact on their survival (Karube et al. 2005).

Generally, miRNAs may function as oncogenes or tumor suppressor genes. Oncogene miRNAs or "oncomirs" usually promote tumor development by inhibiting the tumor suppressor genes or genes involved in control of cell differentiation and/or apoptosis. Their expression is increased in tumors. Tumor suppressor miRNAs are miRNAs that expression is decreased in cancerous cells. They negatively inhibit oncogenes and/or genes that control the cell differentiation or apoptosis (Zhang et al. 2007b). Numerous studies of malignancies, through over-expression or knockdown of some miRNAs, support the involvement of these miRNAs in tumorigenesis.

Kumar et al. (2008) have shown that let-7 functionally inhibits non-small cell tumor development and its over-expression reduces tumor burden in a K-ras 
Table 1

miRNA/mRNA interactions with strong experimental evidence supporting role in physiological function

\begin{tabular}{|c|c|c|c|c|}
\hline & microRNA & $\begin{array}{l}\text { Validated } \\
\text { targets }\end{array}$ & Function & Reference \\
\hline \multirow[t]{9}{*}{ Cancer } & let-7 & RAS & $\downarrow$ regulation of oncogene & Johnson et al. 2005 \\
\hline & $\begin{array}{l}\text { miR-16 } \\
\text { miR-17 }\end{array}$ & VEGF & $\begin{array}{l}\text { regulation of physiological or pathological } \\
\text { angiogenesis }\end{array}$ & Ye et al. 2008 \\
\hline & $\operatorname{miR}-17$ & RND3 & $\downarrow$ regulation of tumor suppressor gene & Luo et al. 2012 \\
\hline & miR-18a & ATM & regulation of apoptosis and DNA repair & Wu et al. 2013 \\
\hline & miR-21 & $\begin{array}{l}\text { PDCD4 } \\
\text { PTEN } \\
\text { RECK }\end{array}$ & $\downarrow$ regulation of tumor suppressor genes & $\begin{array}{l}\text { Asangani et al. 2008; } \\
\text { Xiong et al. 2013; } \\
\text { Zhang et al. } 2008\end{array}$ \\
\hline & miR-21 & $\begin{array}{l}\text { SPRY } \\
\text { TIAM1 }\end{array}$ & $\downarrow$ regulation of oncogene expression & $\begin{array}{l}\text { Sarkar et al. 2010; } \\
\text { Cottonham et al. } 2010\end{array}$ \\
\hline & miR- 31 & $\begin{array}{l}\text { RASA1 } \\
\text { LATS2 } \\
\text { PPP2R2A } \\
\text { RhoBTB1 }\end{array}$ & $\downarrow$ regulation of tumor suppressor genes & $\begin{array}{l}\text { Sun et al. 2013; } \\
\text { Liu et al. } 2010 \text {; } \\
\text { Xu et al. } 2013\end{array}$ \\
\hline & miR-31 & $\begin{array}{l}\mathrm{HDAC} 2 \\
\mathrm{CDK} 2\end{array}$ & regulation of cell cycle and metastases in liver & Kim et al. 2015 \\
\hline & $\begin{array}{l}\operatorname{miR}-34 \\
\operatorname{miR}-214\end{array}$ & E2F3 & regulation of tumor proliferation and apoptosis & $\begin{array}{l}\text { Welch et al. 2007; } \\
\text { Yang et al. } 2015\end{array}$ \\
\hline \multirow{5}{*}{$\begin{array}{l}\text { Hormonal } \\
\text { regulation } \\
\text { of cancer }\end{array}$} & miR-18a & ESR1 & $\begin{array}{l}\text { control of proliferation of hepatocelullar carcinoma } \\
\text { cells }\end{array}$ & Liu et al. 2009 \\
\hline & $\operatorname{miR}-22$ & ESR1 & control of breast cancer proliferation & Xiong et al. 2010 \\
\hline & miR-124 & AR & regulation of various type of tumor growth & Shi et al. 2013 \\
\hline & miR-145 & IRS1 & $\begin{array}{l}\text { inhibition of tumor growth } \\
\text { (GIT cancer) }\end{array}$ & Shi et al. 2007 \\
\hline & miR-206 & ESR1 & control of breast cancer proliferation & Adams et al. 2007 \\
\hline \multirow[t]{4}{*}{$\begin{array}{l}\text { Cardiovascular } \\
\text { system }\end{array}$} & miR-1 & $\begin{array}{l}\text { RasGAP } \\
\text { CDK9 } \\
\text { fibronectin }\end{array}$ & development of cardiac hypertrophy & Sayed et al. 2007 \\
\hline & miR-126 & VCAM1 & regulation of vascular inflammation & Harris et al. 2008 \\
\hline & miR-155 & AGTR1 & regulation of renin-angiotensin system & Zheng et al. 2010 \\
\hline & mirR-208 & THRAP & regulation of stress dependent cardiac growth & $\begin{array}{l}\text { van Rooij and Olson } \\
2009\end{array}$ \\
\hline \multirow[t]{4}{*}{$\begin{array}{l}\text { Circadian } \\
\text { rhythms }\end{array}$} & miR-141 & CLOCK & regulation of circadian rhythms & Kiriakidou et al. 2004 \\
\hline & $\begin{array}{l}\operatorname{miR}-152 \\
\operatorname{miR}-494\end{array}$ & BMAL1 & regulation of circadian rhythms & Shende et al. 2011 \\
\hline & $\operatorname{miR}-185$ & CRY1 & regulation of circadian rhythms & Lee et al. 2013 \\
\hline & $\begin{array}{l}\text { miR-192/194 } \\
\text { cluster }\end{array}$ & $\operatorname{PER}(1-3)$ & regulation of circadian rhythms & Nagel et al. 2009 \\
\hline
\end{tabular}

AGTR1 - angiotensin II receptor type 1; AR - androgen receptor; ATM - ATM serine/threonine kinase; CDK - cyclin-dependent kinase; CRY1 - cryptochrome 1; ESR1 - estrogen receptor 1; E2F3 - E2F transcription factor 3; IRS-1 - insulin like growth factor 1 receptor; LARS - large tumor suppressor 2; PDCD4 - programmed cell death 4; PER - period, PPP2R2A - protein phosphatase 2 regulatory subunit $\mathrm{B}$, alpha; PTEN - phosphatase and tensin homolog; RAS - retrovirus associated sequence oncogene family; RASA1 - RAS p21 protein activator 1; RasGAP - Ras GTPase activating protein; RHOBTB1 - Rho-related BTB domain containing 1; RECK

- reversion inducing cysteine rich protein with kazal motifs; RND3 - Rho family GTPase 3; SPRY - sprouty RTK signaling antagonist 2; THRAP - thyroid hormone receptor (TR) coregulator TR Associated protein 1; TIAM - T-cell lymphoma 
murine lung cancer model. Over-expression of miRlet-7a strongly suppresses proliferation, migration, and invasion of gastric cancer (GC) cells by downregulating the expression of PKM2 (M2 splice isoform of pyruvate kinase), which is a key regulator of aerobic glycolysis (Tang et al. 2016). miR-214 directly targets E2F transcription factor 3 and thus suppresses the tumor proliferation in hepatocellular carcinoma (HCC) cells (Yang et al. 2015). Over-expression of miR-21 enhances tumorigenesis and genetic deletion of miR-21 partially protects against tumor formation in transgenic mice with non-small-cell lung cancer (NSCLC). miR-21 can drive tumorigenesis by inhibiting negative regulators of Ras/MEK/ERK pathway and apoptosis (Hatley et al. 2010). miR-21 seems to down-regulate the core mismatch repair (MMR) recognition protein complex, human mutS homo$\log 2$, and 6 in human colon cancer cell lines. Cells overproducing miR-21 exhibit significantly reduced 5-fluorouracil (5-FU)-induced G2/M damage arrest and apoptosis that is characteristic of defects in the core MMR component (Valeri et al. 2010).

It seems that not only expression but also functions of some miRNAs are cancer specific. miR-31 was significantly up-regulated in colorectal cancer (CRC) (Wang et al. 2009b). In HCT-116 human colon cancer cells, suppression of miR-31 increases the sensitivity to 5-FU at an early stage and effects the cell migration and invasion (Wang et al. 2010b). In serous ovarian cancer, miR-31 is down-regulated and its overexpression inhibits proliferation and induces apoptosis in many serous cancer cell lines with a dysfunctional p53 pathway. However, miR-31 has no effect in other lines with functional p53 (Creighton et al. 2010). The study of Kim et al. (2015) have shown that miR-31 is aberrantly down-regulated in hepatocellular carcinoma and functions as a tumor suppressor by direct regulation of histone deacetylase 2 and cyclin-dependent kinase 2 (Kim et al. 2015).

\section{miRNA and cardiovascular system}

Inflammation plays an important role in host defense, however, is supposed to contribute to many acute and chronic diseases, such as ischemia/reperfusion damage and atherosclerosis (Silvestre et al. 2008). It has been shown that some miRNAs can regulate vascular inflammation. miR-126 is selectively expressed in endothelial cells, targets VCAM-1, suppresses its expression and thereby decreases leukocyte interactions with endothelial cells (Harris et al. 2008).

miRNAs can also be involved in mammalian angiogenesis. In HUVECs, 15 highly expressed miR-
NAs target angiogenic factors (Poliseno et al. 2006) and according to Kuehbacher et al. (2007), miR-27b and let-7 can modulate angiogenesis.

Multiple miRNAs participate in the process of cardiac hypertrophy (Zhang 2008). It has been shown that modulating aberrantly expressed miR-195 is sufficient to modulate hypertrophy (van Rooij et al. 2006). Decreased expression of miR-1 and miR-133 is associated with heart hypertrophy. On the other hand, miR-1 has been shown to be over-expressed in patients with coronary artery disease and silencing of miR-1 in infarcted rat hearts relieved arrhythmogenesis (Yang et al. 2007). miR-21 has been implicated in the regulation neointima lesion formation (Ji et al. 2007).

\section{miRNA and neural system}

miRNAs are important in various aspects of neuronal structure, function, and long-term survival. miRNA dysfunction may promote neuronal degeneration and also subtle deficits in the setting of neurodegenerative disease. Members of miR-29 family appear to have protective effects (Hebert et al. 2006; Kole et al. 2011; Szafranski et al. 2015). On the other hand, other miRNAs may contribute to neurodegenerative diseases by promoting neurotoxic processes (Szafranski et al. 2015). One of such miRNAs is miR144, which positively correlates with human brain aging (Persengiev et al. 2011).

There might be a link between miRNAs and FMRP function (Corbin et al. 2009). FMRP is encoded by FMR1 gene. Transcriptional silencing of the FMR1 seems to account for fragile $\mathrm{X}$ syndrome, which is a common heritable cause of mental retardation (Ishizuka et al. 2002; Garber et al. 2008).

Secretory miRNAs may be a part of the mediation of cell-to-cell communication. Results from Li et al. (2015) have shown that miRNAs can be present in synaptic vesicles (SVs) and suggested that SVs may regulate local protein synthesis by releasing transfer RNA fragments and miRNAs. The mechanism of horizontal transfer of miRNAs is not dependent only on vesicles but can also involve intracellular connections. Results of Zong et al. (2016) have indicated that miRNAs can pass through gap junction channels in a connexin-dependent manner to regulate gene expression in neighboring cells. Authors suggest that gap junctions can be important for intracellular genetic communication to synchronize and coordinate gene expression among cells.

miRNAs appear to comprise a complex regulatory network which likely affects all levels of cellular func- 
tions. Besides above mentioned, miRNAs may play a role in many other processes.

\section{Dynamics of miRNA in the circulation}

The presence of miRNAs in circulation has led to the investigation of miRNAs as a novel diagnostic marker. However, mechanism of miRNAs secretion and their biological function has to be clarified.

The first evidence about the existence of miRNAs in the circulation has been provided by Chim et al. (2008) who identified the placental miRNAs in maternal plasma of pregnant women. It has recently been accepted that miRNA can be analyzed in various body fluids, including plasma, urine, saliva, and semen (Mitchell et al. 2008). miRNA has been reported to be remarkably stable in human plasma and serum in spite of high endogenous RNase activity in the circulation (Mitchell et al. 2008). Besides RNase activity, the serum miRNAs were resistant against treatment with harsh conditions, including digestion with RNase or DNase, low/high pH, extended storage or freeze-thaw cycles (Chen et al. 2008). These qualities increase the possibility of detecting disease states from miRNA analysis in the circulation.

\section{Origin and transport of circulating miRNA}

The remarkable stability of miRNAs in plasma raises a question which mechanisms protect miRNAs from endogenous RNase activity. Three major mechanisms of miRNA secretions have been suggested (Figure 1):

1. passive leakage, as a result of cellular damage (injury, chronic inflammation, apoptosis, necrosis, etc.);

2. active secretion through small membranebound vesicles (microvesicles, exosomes, and apoptotic bodies);

3. active secretion by association with macromolecular complexes: Argonaute proteins and high density lipoprotein (HDL) (Redis et al. 2012).

An intravesicular transport of miRNAs can be carried in exosomes that are small 50-90 nm vesicles. miRNAs stored in circulating vesicles can be released by fusion of the vesicle with the cell membrane. Exosomes contain substantial amounts of RNA (mRNA and miRNAs) (Zampetaki et al. 2012). Kosaka et al. (2010) have found that miRNAs are first incorporated into the exosomal particles after which a surge of cellular ceramide stimulates the release of exosomes. Biosynthesis of ceramide is under regulation of neu- tral sphingomyelinase (nSMase). When HEK293 cells were treated with nSMase inhibitor GW4869, extracellular endogenous miR-16 and miR-146a were reduced in a dose-dependent manner but their cellular expression levels did not change. miRNAs packaged in exosomes can be delivered to recipient cells, where they act through the same mechanism and exert gene silencing as cellular miRNAs (Kosaka et al. 2010). Besides exosomes, miRNAs can be transported by other particles. Microparticles are larger than exosomes (>100 nm diameter) and similarly to exosomes, the miRNA export in microparticles is an actively regulated process. miRNAs are also present in the apoptotic bodies which arise as a response to apoptotic stimuli (Zampetaki et al. 2012).

It remains elusive, how miRNAs are sorted into exosomes for their secretion. Different composition of RNA between a donor cell and extracellular vesicles suggests that there are specific mechanisms, which enrich RNAs within secreted vesicles. Two types of extracellular vesicles, both described as exosomes, can differ in their composition even if they are secreted by the same cell (Jose 2015). It appears that sorting of specific miRNA species to exosomes is an actively regulated process. The study conducted by Squadrito et al. (2014) has shown that miRNA sorting into exosomes is partly modulated by changes of miRNA target levels in the producer cells.

Secretory miRNAs have been hypothesized to participate in the mediation of cell-to-cell communication. However, it is not clear whether all extracellular miRNAs are associated with exosomes (Ma et al. 2012). Wang et al. (2010a) have proposed that significant proportion of extracellular miRNAs can escape from the cell in exosome-independent manner. A variety of RNA-binding proteins, especially nucleophosmin 1 (NPM1), were released together with miRNAs into cell culture medium. NMP1 may play a role in the packaging and perhaps exporting the extracellular miRNAs (Wang et al. 2010a). According to Turchinovich et al. (2011), only a small minority of extracellular miRNAs can be associated with exosomes. However, in comparison with Wang et al. (2010a), their data have suggested that the extracellular miRNAs are bound to Ago2. They hypothesized that a large portion of the extracellular circulating miRNAs are by-products of dead or dying cells, persisting in the extracellular space due to the stability of the miRNA/Ago2 complex. However, the authors do not decline the possibility that some miRNAs could be associated with exosomes. Another study has confirmed that vesicle-associated plasma miRNAs represent a minority, while the majority is pres- 


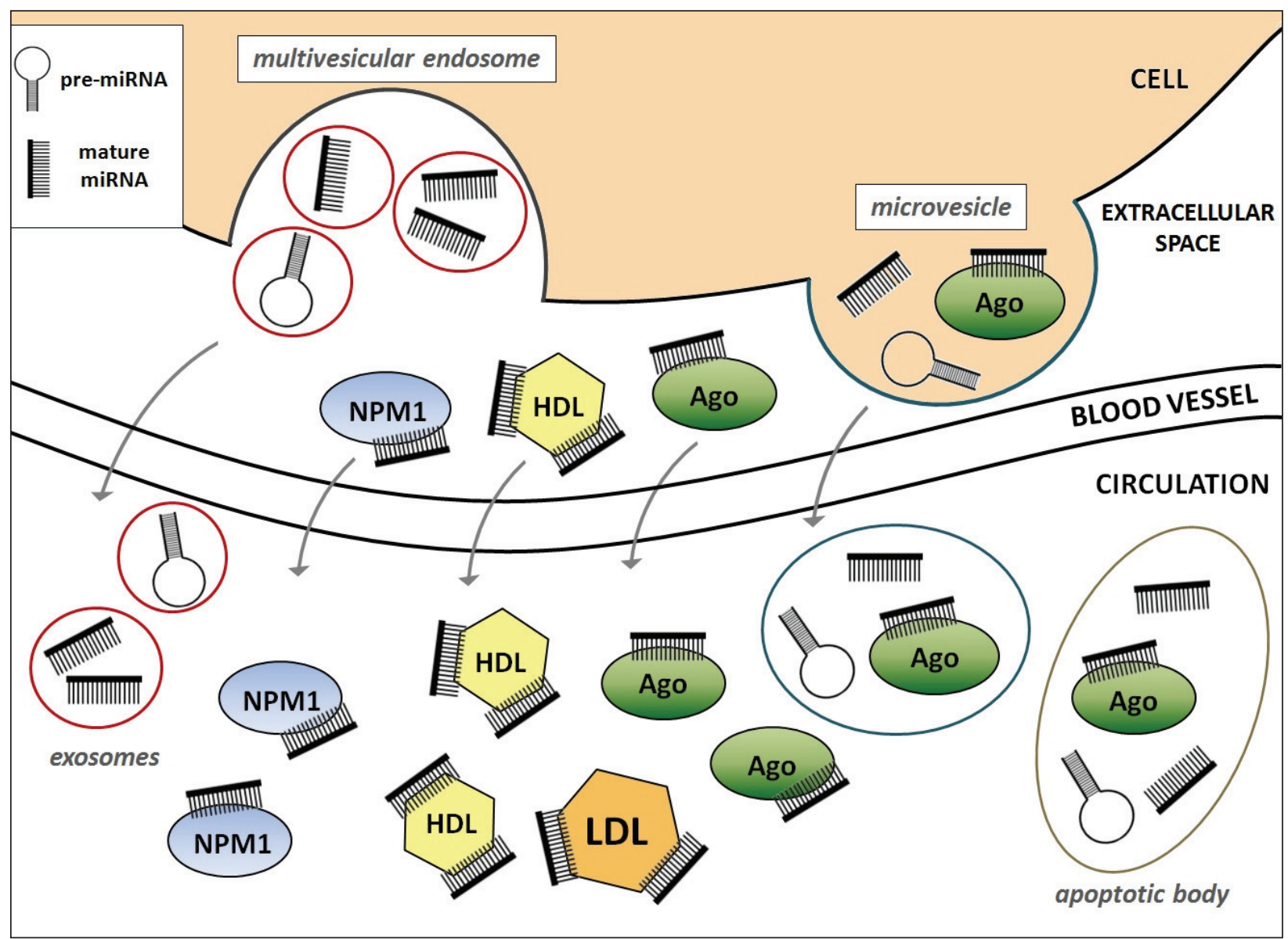

Figure 1. miRNAs in circulation may be transferred in several ways: they can be carried by vesicles (exosomes, microparticles, apoptotic bodies), protein complexes (NPM1, Ago) and lipoprotein complexes (HDL, LDL). Although numerous tissues can contribute to the circulating miRNA levels, miRNAs derived from blood cell represent a considerable part. HDL - high-density lipoprotein; LDL - low-density lipoprotein; Ago - Argonaute; NPM-1 -nucleophosmin 1; based on the data from Wang et al. (2010a), Turchinovich et al. (2011), Pritchard et al. (2012) and Redis et al. (2012).

ent in protein complexes (Ago2) protecting miRNAs from plasma RNase (Arroyo et al. 2011). Ferreira et al. (2014) have demonstrated that AVM-BEC secretes RNA-binding protein Ago2, which is involved in part in the mediation of miR-18a delivery to brain endothelial cells. Moreover, miR-18a delivered by Ago2 is functionally active in both in vitro and in vivo conditions.

It has been proposed that miRNAs can also be carried in lipoprotein complexes. Vickers et al. (2011) have shown that high-density lipoprotein (HDL) can transport endogenous miRNAs and facilitate their delivery to recipient cells with functional targeting capabilities. The export of miR-223 to HDL has been found to be inhibited by nSMase2. It has been sug- gested that the export of specific miRNAs through the exosomal pathway and the HDL pathway could be distinct and possibly opposing mechanisms, although they are both likely regulated by nSMase2 activity and ceramide synthesis. miRNAs appear to be present also in low-density lipoprotein (LDL). It seems that HDL and LDL may share many of the most abundant miRNAs, but miRNA profiles differ from each other (Vickers et al. 2011).

\section{Import of miRNA into cells}

Once being secreted into the extracellular space, exosomes are distributed through the body fluids and reach target tissues and cells. It appears that the most 
common way of extracellular vesicles (EV) uptake is endocytosis, including its subtypes such as macropinocytosis, phagocytosis, clathrin-mediated endocytosis, and caveolin-dependent endocytosis (Mulcahy et al. 2014).

Mulcahy et al. (2014) have reviewed several pathways, which may participate in the uptake of EV. Those mechanisms, among others, include protein interactions, which can facilitate endocytosis of EV. In a recent study, ovarian carcinoma cell line SKOV3 and its exosomes were treated with protease $\mathrm{K}$. After protease $\mathrm{K}$ administration, the exosome uptake was decreased, indicating that proteins that mediate the exosome internalization are present on the surface of cells and exosomes (Escrevente et al. 2011). Many classes of proteins (tetraspanins, integrins, immunoglobulins, proteoglycans, lectins, clathrin and caveolin) are likely to play a role in the interactions with membrane receptors and mediation of attachment and uptake of EV into cells. The EV can deliver their cargo also by direct fusion of its membrane with the cell plasma membrane (Mulcahy et al. 2014).

It has also been observed that exosomes can be taken up via lipid raft domain. Disrupted exosomal lipid rafts resulted in an inhibition of internalization of exosomes. Annexins (mainly AnxA2 and AnxA6) were essential for exosome, trafficking in BT-549 breast carcinoma cell line (Koumangoye et al. 2011).

A question of EV uptake specificity is not fully understood. Evidence is inconclusive in this respect. While some authors propose that EV are taken up by various cell types, others are suggesting that uptake of EV is a specific process, occurring only in the case of a correct combination of ligand and receptor between cell and vesicle (Mulcahy et al. 2014).

\section{Exogenous miRNA}

The possibility that miRNAs may regulate distant cells in one organism naturally raised a question whether even exogenous miRNAs obtained from other sources may have the same influence on gene expression. Some recent studies have suggested that exogenous miRNAs might have that capability. According to Zhang et al. (2012), exogenous plant mature miR-168a can pass in food through gastrointestinal (GI) tract into the bloodstream and tissues and regulate the translation of its target gene in a fashion of mammalian functional miRNA. In another study, survival of an exogenous RNA was investigated in mice fed with plant RNA from Brassica oleacea. Exogenous plant miRNAs were detected in sera, feces, and several tissues. Therefore, it has been proposed that they may survive in GI tract of mice and enter the peripheral blood and organs (Liang et al. 2014). In addition, miRNAs, derived from cow milk, seem to influence gene expression in human (Baier et al. 2014). However, the function of extracellular miRNAs, obtained from nutrition, raises many questions. Title et al. (2015) have investigated intestinal miRNA uptake in newborn miRNA knockout mice fed with milk from wild-type foster mothers. Analysis of several tissues did not reveal detectable miRNA uptake from milk despite the fact that miRNAs are present in milk at high levels. Further investigation showed that milk miRNAs are degraded in intestinal fluid. Authors have accepted a possibility that the small uptake level, which cannot be detected, is insufficient for the canonical miRNA function and thus milk miRNAs are more likely to represent a nutritional source (Title et al. 2015). Dietary xenomiRNAs are a subject of an intense discussions (Witwer and Hirschi 2014) and further analysis are needed to elucidate their transfer and functional consequences.

\section{How can be miRNA used in medicine?}

Since the discovery of miRNAs in the blood and body fluids, there is an intensive effort to reveal miRNA potential to be used as biomarkers. Several examples implicate that miRNAs reflect physiological state of the organism. Placenta specific miRNAs present in human plasma during pregnancy rapidly dropped after delivery. Authors of this study have demonstrated that placenta specific miRNAs are likely to be continuously released by exosomes from chorionic villi into maternal circulation and may target maternal tissues (Luo et al. 2009). Circulating plasma levels of miR-34a correspond to levels in the cochlea and auditory cortex during aging in mice. Thus, circulating miR-34a may reflect ongoing cell loss in auditory organs during the age-related hearing loss (Pang et al. 2016). Anyway, changes in miRNA levels are investigated much more in relation to disease with intention to improve existing diagnostic tools. The second cardinal interest is focused on the delivery of artificial miRNAs or miRNAs silencers to cure a disease.

\section{miRNA-based biomarkers}

The ideal biomarker should fulfill several criteria such as high specify to disease or organ, accessibility through non-invasive methods, sensitive to change in pathology process, and ability to early detect the disease before appearance of the clinical symptoms. Beside diagnostic markers, there is also a need for 
prognostic markers that could predict disease outcome and progression of patient survival (Etheridge et al. 2011).

However, there is still not enough information available regarding the origin of miRNAs in the circulation. It is likely that a considerable portion of circulating miRNAs is derived from blood cells and organs. Recently, $58 \%$ of examined miRNAs that have been previously reported as circulating cancer biomarkers were found to be highly expressed in several types of blood cells. The majority of the biomarkers was also present in healthy plasma; however, at basal levels. Comparison of expression profiles of miRNAs in plasma to profiles of blood cells revealed that miRNA expression in plasma mirrors one of the blood cells. In addition, changes in blood cell counts and hemolysis may have significant impact on plasma miRNA biomarker levels (up to 50-fold) (Pritchard et al. 2012).

Besides the above-mentioned complications, it is still a need to clarify whether miRNAs changes observed in the circulation are the result of cell death or cell secretion.

Circulating miRNAs in cancer. Identification of robust differences in miRNA patterns, observed in different cancer types and between cancer and healthy tissue, led to an idea that miRNA pattern could be used to diagnose specific type of oncologic malformations (Mogilyansky and Rigoutsos 2013). A lot of attention has been paid to the potential of circulating miRNAs as biomarkers of cancer.

Expression of particular miRNA can be increased or decreased in cancer tissue (Lu et al. 2005). Mogilyansky and Rigoutsos (2013) have observed downregulation of miRNA expression in the cancer tissue. On the other hand, some miRNAs have been shown to be up-regulated in cancer tissue, e.g. miRNAs from oncogenic cluster miR-17-92 (Mogilyansky and Rigoutsos 2013).

Unfortunately, circulation does not reflect miRNA expression tissue pattern perfectly. Besides, many circulating miRNAs, associated with cancer, may reflect a secondary effect on blood cells (Pritchard et al. 2012). Cancer-associated miRNAs in circulation may possibly originate in immunocytes. Tumor cells secrete a scale of miRNAs, modulating immune response in immunocytes that determines immunostimulatory or an immunotolerant tumor environment. Immunocytes may, vice versa, secrete miRNAs influencing tumor and thus promote or inhibit proliferation, invasion, and apoptosis. Therefore, the cancer-associated miRNAs in circulation may have origin in the immune system and their dysregulation may represent a link between the cancer and immunity (Ma et al. 2012). These findings may point out on the importance of several possible sources of circulating miRNAs when assessing their potential as biomarkers.

According to Mitchell et al. (2008), it is likely that many miRNAs expressed in tumor can affect the biological behavior and clinical phenotype of the tumor. Tumor cells secrete exosomes containing miRNAs that influence both the tumor and normal cells (Katsuda et al. 2014). Most of the tumor-secreted exosomal miRNAs are oncogenic but some cell lines (for example metastatic gastric cancer cell lines) secret predominantly tumor suppressor let-7 miRNA, which could represent a way how the tumor cells may get rid of the tumor inhibiting miRNAs to maintain their oncogenesis and invasiveness (Ohshima et al. 2010). Kosaka et al. (2010) have hypothesized that miRNAs down-regulated in cancer cells are compensated during the initial stage of the tumorigenesis by the surrounding cells, supplying exosomes containing the decreased miRNAs. However, once the surrounding cells cannot meet the demand, cancer cells enter an advanced stage.

Fluid-based biomarkers, currently used for cancer diagnostics, are mainly proteins (e.g. alpha-fetoprotein, chromogranin A, nuclear matrix protein 22, carbohydrate antigen 125), enzymes (e.g. prostate specific antigen), human chorionic gonadotropin, specific gene mutations, and others. In spite of the high number of recently used biomarkers, their clinical application is limited because of their low sensitivity and specificity. Therefore, the need for novel biomarkers is constantly growing (Ma et al. 2012).

Subgroup and meta-regression analysis of Zeng et al. (2015) have demonstrated that multiple miRNAs have higher predictive accuracy than a single one. According to their results, serum appears to a better matrix for miRNA assays than plasma in screening colorectal carcinoma (CRC). Identification of the relationship between tissue miRNAs and circulating miRNAs would noticeably help to elucidate the origin of circulating miRNAs. Study from Mitchell et al. (2008) has shown that tumor-derived miRNAs can enter circulation and serve as a means for cancer detection. They also have revealed a moderate correlation when compared plasma levels of miR-629 and miR-660 with tumor mass in mice. Toiyama et al. (2013) have observed a significant correlation between miR-21 expression in tissues and serum of patients with CRC. High levels of miR-21 in tissues as well as serum were associated with a large tumor size, 
distant metastasis, and advanced TNM stage. Results have suggested that circulating miR-21 in serum may be produced by CRCs because of a significant drop in serum miR-21 levels in postoperative serum (Toiyama et al. 2013). miR-592 level in serum and CRC tissue was also up-regulated in CRC patients and significantly decreased in postoperative serum compared to the preoperative serum level (Liu et al. 2015). Cheng et al. (2011) have observed that circulating levels of miR-141 are associated with metastatic CRC in stage IV and could serve as a prognosis marker to predict poor outcome and survival.

However, only miR-375 of five investigated miRNAs (miR-150, miR-375, miR-125b, miR-206 and miR-126) showed correlation between tissue and plasma samples in CRC (Xu et al. 2014). Pigati et al. (2010) have revealed that about $66 \%$ and not all of the released miRNAs are at an abundance closely reflecting the cellular miRNA abundance of malignant mammary epithelial cells. Results of these authors have indicated that miRNAs are released partially selectively, which is important in considering diagnostic value of circulating miRNAs and assessing biological significance of released miRNAs (Pigati et al. 2010).

A number of miRNAs with decreased levels have also a high diagnostic potential. miR-601 and miR760 showed reduced levels in plasma of patients with advanced adenoma (Wang et al. 2012a). Other examples of down-regulated miRNAs in serum are miR194 and miR-29b that inversely correlated with the cancer stage (Basati et al. 2015). Reduced plasma levels of miR-24, miR-320a, and miR-423-3p have been observed in patients with CRC and benign lesions. Their levels increased after surgery of patients with clinical improvement (Fang et al. 2015).

A release of miRNA from cancer tissue has been studied with the use of prostate cancer xenograft implanted to immunocompromised mice. Results have shown that the levels of non-tumor specific miRNAs were not increased in mice plasma, while tumor specific miRNA were significantly elevated. Authors supposed that miRNAs, originated from prostate cancer tissue, could be measured in the circulation. They observed significantly increased serum levels of miR-141 in patients with prostate cancer compared to healthy controls (Mitchell et al. 2008). Another study has implicated elevated expression of miR-26a, as marker discriminating, between patients with prostate cancer and benign prostate hyperplasia (Mahn et al. 2011). miRNA-375 and miRNA-141 have been reported to be up-regulated in cancer tissue compared to benign prostate tissue samples and were implicated as circulating markers of high-risk tumor (Brase et al. 2011).

Both the tissue and serum levels of miR-128 were significantly decreased in patients suffering from prostate cancer and a close correlation between tissue and serum levels has been observed (Sun et al. 2015).

In patients suffering from the renal cell carcinoma (RCC), increased levels of 109 miRNAs were observed in the circulation compared to healthy controls, however, only 36 miRNAs were increased in cancer tissue as well plasma in RCC patients. This may indicate that only a small subset of circulating miRNAs has a tumor-specific origin. Increased miR-1233 values correlated with incidence of RCC, however, increase in miR-1233 levels was observed also in patients with angiomyolipoma or oncocytoma (Wulfken et al. 2011).

Measurements of miRNA in other body fluids, e.g. saliva or urine, can be also used for cancer diagnosis. Concentrations of miR-126 and miR-182 have been reported to be increased in urine of patients suffering from bladder cancer compared to control (Hanke et al. 2009). Up-regulation of miR-618 and down-regulations of miR-650 concentrations in urine has been suggested for early detection of hepatocellular carcinoma in high-risk hepatitis $C$ virus infected patients (Abdalla and Haj-Ahmad 2012). Approximately 50 miRNAs have been discovered in saliva of healthy probands in stable levels, protected from degradation and two of them (miR-200a and miR-125a) were present in significantly lower levels in samples from patients with oral squamous cells carcinoma (Park et al. 2009).

Using circulating miRNA as biomarkers is complicated by the fact that their circulating levels are coming from different sources and that miRNAs from circulation can reflect every aspect of the human physiological state (Ma et al. 2012). It is important to note that some miRNAs show lack of disease specificity. Since their up/down-regulated serum levels are present in various types of cancer, they may be useful as an universal rather than cancer specific markers (Hrustincova et al. 2015). Typical example is miR-21 that has been reported to be significantly changed in the circulation of patients with 5 solid tumors: breast, lung, colorectal, esophageal, and gastric cancer (Wang and Zhang 2012). Based on the recent knowledge about miRNA changes in circulation of cancer patients, diagnostic company Rosetta Genomics is currently offering clinical test by using miRNA profile that is able to identify the origin of metastatic cancer when the primary origin of metastasis is not clear (Hydbring and Badalian-Very 2013). 
miRNAs and endocrine diseases. miRNAs have been evaluated as biomarkers of endocrine diseases as well. They have been shown to be relevant in several organs, which are directly related to glucose metabolism (pancreatic islet, skeletal muscle, liver, brain and adipose tissue). They can play a role in the insulin secretion and potentially in type 2 diabetes progression (Poy et al. 2007).

Reduced levels of several miRNAs were found in plasma of patients suffering from diabetes mellitus type 2 . These results have been confirmed in animal model of hyperglycemia where high glucose concentration in circulation was associated with increased levels of miR-126 in endothelial apoptotic bodies (Zampetaki et al. 2010). Another study has proposed a significant decline in serum miR-23 as a potential biomarker for early detection of diabetes mellitus type 2 and pre-diabetes stages (Yang et al. 2014). In the serum of children with diabetes mellitus type 1,12 up-regulated miRNAs have been identified, whereas miR-25 was negatively associated with residual betacell function and positively associated with glycemic control (Nielsen et al. 2012). In patients with metabolic syndrome levels of circulating miR-197, -23a, $-509-5 \mathrm{p},-130 \mathrm{a},-195,-27 \mathrm{a}$, and $-320 \mathrm{a}$ were increased. Diseases contributing to metabolic syndrome were associated with specific miRNAs, e.g. miR-197, miR23a, and miR-509-5p were correlated with dyslipidemia, while miR-130a and miR-195as with hypertension (Karolina et al. 2012). In the mouse model of obesity, a correlation between circulating level of miR-130b and BMI index has been observed. According to the above-mentioned authors, miR-130b may reflect the degree of obesity and metabolic syndrome better than triacylglycerol levels in the plasma (Wang et al. 2013).

Other examples. In animal model, several miRNAs were more than 2-fold up-regulated or downregulated in the hippocampal tissue and circulation after ischemic strokes, brain hemorrhage or kainateinduced seizures. This implicates a possible use of miRNAs as biomarkers of brain injury or neurologic disease (Liu et al. 2010a).

Circulating miRNAs have been suggested to be a promising biomarker for hepatocytes injury, caused by various factors (drugs, alcohol, some specific herbs) or inflammation liver disease. Correlation of changed particular miRNA level with particular liver disease can provide further information about the mechanisms involved in liver pathology (Wang et al. 2009a; Su et al. 2012; Hornby et al. 2014). Several serum miRNAs have been implicated to have a high potential for early detection of acute kidney injury (Aguado-Fraile et al. 2015). Intensive research has also been focused on the identification of miRNA-based biomarkers for autoimmune disease, such as rheumatoid arthritis (miR-24 and miR-125-5p), lupus erythematosus (miR-126) or autoimmune thyroid diseases (Wang et al. 2012b; Murata et al. 2013; Yamada et al. 2014).

By using an isoproterenol-induced cardiac injury in rats, a correlation between myocardial injury and plasma concentration of miR-208 was found. Moreover, miR-208 plasma levels showed a similar patter like cardiac troponin I that is accepted as a classic marker of myocardial injury (Ji et al. 2009). Concentration of the heart specific miR-499 in plasma also shows a significant correlation with the level of blood troponin I in patients with acute infarction of myocardium (Adachi et al. 2010). Plasma concentration of miR-519e-5p shows a decreased level after myocardium infarction but without association with ischemic stroke or pulmonary embolism. Therefore, it has been suggested as a specific marker of myocardium infarction (Wang et al. 2014). Several other miRNAs, showing reduced levels in circulation after ischemic stroke, were implicated as potential biomarkers that can distinguish healthy control from patients (Long et al. 2013).

Novel miRNA-dependent biomarkers may greatly improve the diagnosing or monitoring of early events in diseases and could help to start treatment earlier. However, all the above-mentioned potential biomarkers need to be further evaluated before proceeding to actual clinical applications.

\section{siRNA and miRNA based therapeutics}

There is a strong experimental effort focused on the development of artificial interfering RNAs for therapeutic use. Since longer double-stranded RNA (>30nt) shows a non-specific inducing of interferon immune response in mammalian cells, it was greatly appreciated that shorter ribonucleotide dsRNA can induce specific silencing in mammalian cells (Elbashir et al. 2001).

Small interfering RNA (siRNA) has been employed in studies focused on RNA interference in mammalian cells sooner than miRNA. miRNA and siRNA share a number of similarities, however, not all of their features are identical. The most important difference resides in the target specificity. Whereas, miRNAs can recognize multiple targets and show partial complementarity with them, siRNAs are highly specific and target only one mRNA. They are 
currently used for silencing of specific genes that can be beneficial in treating single gene disorders like hemophilia or hereditary amyloidosis.

Therapeutic application of interfering RNAs is very promising. However, to be generally acceptable, it needs to overcome several problems. Before its application, delivery, specificity of targeting, and stability of artificial interfering RNAs have to be improved. Chemical modification of dsRNAs is often used to improve the stability and minimize the effect on immune system.

There are several ways how to successfully deliver siRNA to organ, tissue or cell type without using virus-based delivery systems. The most intensively studied delivery methods are based on specific carries that can be - liposomes (vesicles having phospholipid bilayer), polymeric nanoparticles, polymeric micelles, dendrimers or metallic core nanoparticles (Gavrilov and Saltzman 2012). Loading of siRNA into liposomes is a very promising strategy how to deliver the siRNA into the target organ. This system employs liposomes mediating fusion of siRNA cargo with the host cells. Moreover, neutral lipids are rather nontoxic and generally do not activate immune system response. Nanoparticles delivery systems offer high stability and controlled release of siRNA cargo via leaky vasculature in tumors. In case of using metallic nanoparticle, it is possible to tract distribution of nanoparticles via magnetic resonance imaging (Gavrilov and Saltzman 2012; Zuckerman and Davis 2015).

The first successful therapeutic delivery of siRNA has been performed by Koldehoff et al. (2007). bcr$a b l$ siRNA delivered in liposomes administered to human oncological patient successfully inhibited over-expressed oncogene and resulted into increased apoptosis of cancer cells. However, this study was conducted only with single patient with chronic myeloid leukemia. Another clinical trial used nanoparticles to deliver siRNA to cells of solid cancer. Successful administration of nanoparticles and siRNA has been confirmed by its intracellular localization in tumor tissue and absence in adjacent epidermis and decrease in target mRNA expression in tumor tissue (Davis et al. 2010). Recently, the number of clinical studies, using RNA interference based therapy focused on treating of chronic myeloid leukemia, metastatic melanomas, and other solid tumors, is increasing.

Except of cancer treatment, clinical trials have been focused on the cure of HIV, hypercholesterolemia, glaucoma, and diabetic macular edema (Deng et al. 2014; http://clinicaltrials.gov/). siRNA based therapy was successfully used for preparation of na- sal spray that directly target mRNA of the respiratory syncytial virus. This therapy had successful outcome with significant antiviral activity (DeVincenzo et al. 2010).

The therapeutic potential of miRNA is emerging as well. Researchers are using two approaches to develop miRNA-based therapeutics. The first one is aimed on the development of miRNA silencers (antagomirs) that are specifically designed to inhibit endogenous production of miRNAs. This method was used in clinical trial focused on blocking liverexpressed miR-122. It has been found to be effective therapeutic approach in hepatitis $\mathrm{C}$ infection. Chemically modified antisense oligonucleotides that sequester mature miR-122 administered to hepatocytes was able to block replication of the virus (Janssen et al. 2013). Administration of the antisense oligonucleotides, designed to inhibit of miR-208a, showed that systemic silencing of miR-208a, a miRNA previously described as responsible for stress dependent cardiac remodeling and hypertrophy, prevents pathologic cardiac remodeling and diastolic dysfunction. These effects have been observed only in the relation to cardiac stress response and not normal cardiac development (van Rooij et al. 2007).

Another approach using miRNA replacement therapy, known as miRNA mimics, can restore reduced miRNA level and resume lost physiological function. Using of miRNA mimics is often suggested as an efficient way for cancer therapy, because of the down-regulated miRNAs in tumors that are frequently functioning as tumor-suppressors. let-7 has previously been reported to target oncogene K-ras that is frequently mutated in several types of solid tumors. Therapeutic delivery of let-7 seems to be effective in robust inhibition of tumor growth. Phase I study, focused on anti-cancer therapeutics employing miR-34 mimics, is ongoing. miR-34 is a well-known tumor suppressor that is engaged in p53 pathway and the anti-cancer effects mediated by miR-34 were observed in several solid tumors (liver, spleen, and kidney). This clinical trial is now recruiting new patients with liver carcinoma (Daige et al. 2014; Zuckerman and Davis 2015). Another miRNA replacement based therapeutic is miR-16 mimics that is indicated in malignant pleural mesothelioma and non-small-cell lung cancer. This therapy uses nanoparticle drug delivery system and the study is expected to be finished in mid-2016 (Lam et al. 2015).

Regenerative medicine also employs miRNA replacement therapy. It has been observed that nanoparticle delivery of proangiogenic miR-132 to endothelial cells before transplantation may enhance 
the transplantation process via sensitizing cells to the effects of endogenous growth factors (Devalliere et al. 2014). miRNA cluster miR302-367 plays an important role in cardiomyocyte proliferation during development. Study based on the postnatal reactivation of miR-302-367 cluster have shown an increased cardiomyocytes proliferation and reduced scar formation after experimental myocardial infarction (Tian et al. 2015). Therapy with enhanced expression of miR-26a led to a better bone reparation due to increased angiogenesis and osteogenesis ( $\mathrm{Li}$ et al. 2013).

All above mentioned siRNA and miRNA focused studies have shown that this novel class of therapy can be safely dosed to human to alleviate symptoms or treat diseases. However, more preclinical and clinical human trials are needed to be conducted to reach the final prove of this therapy for clinical practice.

\section{Conclusions and perspectives}

Significance of miRNA focused experimental field is growing and closely connected to ongoing research in human physiology and medicine. A summary of strong experimental evidence about the role of particular miRNAs in regulation of physiological processes and their involvement in pathologies is reviewed. Cells actively release miRNAs into the intracellular space and circulation and spectrum of excreted miRNAs reflects cell state. miRNAs have been reported to be surprisingly stable in the circulation and therefore, useful for diagnostic purposes. Circulating miRNAs have been associated with physiological and pathological states, including various cancer types, cardiovascular diseases, sclerosis, liver injury or pregnancy. Although, several diagnoses have successfully been connected with increased or decreased levels of miRNA in the circulation, problem of a possible contamination by miRNA from blood cells and other sources in the organism is persisting. Many questions are still not answered. Mechanisms how intercellular signaling of miRNAs in the organism is executed are still misty, although, the first experimental evidence, supporting extracellular signaling mediated by miRNA, is emerging. Delivery of artificial miRNAs is still struggling with insufficient stability of oligonucleotides and proper targeting of tissue, but progress in this field is evident and synthetic miRNAs have already being tested in clinical trials.

\section{Acknowledgements}

This work was supported by grants VEGA 1/0499/15, APVV-0291-12 and APVV-14-0318.

\section{References}

Abdalla MA, Haj-Ahmad Y. Promising Candidate Urinary MicroRNA Biomarkers for the Early Detection of Hepatocellular Carcinoma among High-Risk Hepatitis C Virus Egyptian Patients. J Cancer 3, 19-31, 2012. http:// dx.doi.org/10.7150/jca.3.19

Adachi T, Nakanishi M, Otsuka Y, Nishimura K, Hirokawa G, Goto Y, Nonogi H, Iwai N. Plasma microRNA 499 as a biomarker of acute myocardial infarction. Clin Chem 56, 1183-1185, 2010. http://dx.doi.org/10.1373/ clinchem.2010.144121

Adams BD, Furneaux H, White BA. The micro-ribonucleic acid (miRNA) miR-206 targets the human estrogen receptor-alpha (ERalpha) and represses ERalpha messenger RNA and protein expression in breast cancer cell lines. Mol Endocrinol 21, 1132-1147, 2007. http://dx.doi.org/10.1210/me.2007-0022

Aguado-Fraile E, Ramos E, Conde E, Rodriguez M, Martin-Gomez L, Lietor A, Candela A, Ponte B, Lia-o F, GarciaBermejo ML. A Pilot Study Identifying a Set of microRNAs As Precise Diagnostic Biomarkers of Acute Kidney Injury. PLoS One 10, e0127175, 2015. http://dx.doi.org/10.1371/journal.pone.0127175

Arroyo JD, Chevillet JR, Kroh EM, Ruf IK, Pritchard CC, Gibson DF, Mitchell PS, Bennett CF, Pogosova-Agadjanyan EL, Stirewalt DL, Tait JF, Tewari M. Argonaute2 complexes carry a population of circulating microRNAs independent of vesicles in human plasma. Proc Natl Acad Sci U S A 108, 5003-5008, 2011. http://dx.doi. org/10.1073/pnas.1019055108

Asangani IA, Rasheed SA, Nikolova DA, Leupold JH, Colburn NH, Post S, Allgayer H. MicroRNA-21 (miR-21) posttranscriptionally downregulates tumor suppressor Pdcd 4 and stimulates invasion, intravasation and metastasis in colorectal cancer. Oncogene 27, 2128-2136, 2008. http://dx.doi.org/10.1038/sj.onc.1210856

Baier SR, Nguyen C, Xie F, Wood JR, Zempleni J. MicroRNAs are absorbed in biologically meaningful amounts from nutritionally relevant doses of cow milk and affect gene expression in peripheral blood mononuclearcells, HEK293 kidneycell cultures, and mouse livers. J Nutr 144, 1495-1500, 2014.http://dx.doi.org/10.3945/jn.114.196436 
Basati G, Razavi AE, Pakzad I, Malayeri FA. Circulating levels of the miRNAs, miR-194, and miR-29b, as clinically useful biomarkers for colorectal cancer. Tumour Biol [Epub ahead of print], 2015.

Brase JC, Johannes M, Schlomm T, Falth M, Haese A, Steuber T, Beissbarth T, Kuner R, Sultmann H. Circulating miRNAs are correlated with tumor progression in prostate cancer. Int J Cancer 128, 608-616, 2011. http:// dx.doi.org/10.1002/ijc.25376

Chen X, Ba Y, Ma L, Cai X, Yin Y, Wang K, Guo J, Zhang Y, Chen J, Guo X, Li Q, Li X, Wang W, Zhang Y, Wang J, Jiang X, Xiang Y, Xu C, Zheng P, Zhang J, Li R, Zhang H, Shang X, Gong T, Ning G, Wang J, Zen K, Zhang J, Zhang CY. Characterization of microRNAs in serum: a novel class of biomarkers for diagnosis of cancer and other diseases. Cell Res 18, 997-1006, 2008. http://dx.doi.org/10.1038/cr.2008.282

Cheng H, Zhang L, Cogdell DE, Zheng H, Schetter AJ, Nykter M, Harris CC, Chen K, Hamilton SR, Zhang W. Circulating plasma MiR-141 is a novel biomarker for metastatic colon cancer and predicts poor prognosis. PLoS One 6, e17745, 2011. http://dx.doi.org/10.1371/journal.pone.0017745

Chim SS, Shing TK, Hung EC, Leung TY, Lau TK, Chiu RW, Lo YM. Detection and characterization of placental microRNAs in maternal plasma. Clin Chem 54, 482-490, 2008. http://dx.doi.org/10.1373/clinchem.2007.097972

Corbin R, Olsson-Carter K, Slack F. The role of microRNAs in synaptic development and function. BMB Rep 42, 131-135, 2009. http://dx.doi.org/10.5483/BMBRep.2009.42.3.131

Cottonham CL, Kaneko S, Xu L. miR-21 and miR-31 converge on TIAM1 to regulate migration and invasion of colon carcinoma cells. J Biol Chem 285, 35293-35302, 2010. http://dx.doi.org/10.1074/jbc.M110.160069

Creighton CJ, Fountain MD, Yu Z, Nagaraja AK, Zhu H, Khan M, Olokpa E, Zariff A, Gunaratne PH, Matzuk MM, Anderson ML. Molecular Profiling Uncovers a p53-Associated Role for MicroRNA-31 in Inhibiting the Proliferation of Serous Ovarian Carcinomas and Other Cancers. Cancer Res 70, 1906-1915, 2010. http://dx.doi. org/10.1158/0008-5472.CAN-09-3875

Daige CL, Wiggins JF, Priddy L, Nelligan-Davis T, Zhao J, Brown D. Systemic delivery of a miR34a mimic as a potential therapeutic for liver cancer. Mol. Cancer Ther 13, 2352-2360, 2014. http://dx.doi.org/10.1158/1535-7163. MCT-14-0209

Davis ME, Zuckerman JE, Choi CH, Seligson D, Tolcher A, Alabi CA, Yen Y, Heidel JD, Ribas A. Evidence of RNAi in humans from systemically administered siRNA via targeted nanoparticles. Nature 464, 1067-1070, 2010. http://dx.doi.org/10.1038/nature08956

Deng Y, Wang CC, Choy KW, Du Q, Chen J, Wang Q, Li L, Chung TK, Tang T. Therapeutic potentials of gene silencing by RNA interference: principles, challenges, and new strategies. Genes 538, 217-227, 2014. http://dx.doi. org/10.1016/j.gene.2013.12.019

Devalliere J, Chang WG, Andrejecsk JW, Abrahimi P, Cheng CJ, Jane-wit D, Saltzman WM, Pober JS. Sustained delivery of proangiogenic microRNA-132 by nanoparticle transfection improves endothelial cell transplantation. FASEB J 28, 908-922, 2014. http://dx.doi.org/10.1096/ff.13-238527

DeVincenzo J, Lambkin-Williams R, Wilkinson T, Cehelsky J, Nochur S, Walsh E, Meyers R, Gollob J, Vaishnaw A. A randomized, double-blind, placebo-controlled study of an RNAi-based therapy directed against respiratory syncytial virus. Proc Natl Acad Sci U S A 107, 8800, 2010. http://dx.doi.org/10.1073/pnas.0912186107

Elbashir SM, Harborth J, Lendeckel W, Yalcin A, Weber K, Tuschl T. Duplexes of 21-nucleotide RNAs mediate RNA interference in cultured mammalian cells. Nature 411, 494-498, 2001. http://dx.doi.org/10.1038/35078107

Escrevente C, Keller S, Altevogt P, Costa J. Interaction and uptake of exosomes by ovarian cancer cells. BMC Cancer 11, 108, 2011. http://dx.doi.org/10.1186/1471-2407-11-108

Etheridge A, Lee I, Hood L, Galas D, Wang K. Extracellular microRNA: a new source of biomarkers. Mutat Res 717, 85-90, 2011. http://dx.doi.org/10.1016/j.mrfmmm.2011.03.004

Fang Z, Tang J, Bai Y, Lin H, You H, Jin H, Lin L, You P, Li J, Dai Z, Liang X, Su Y, Hu Q, Wang F, Zhang ZY. Plasma levels of microRNA-24, microRNA-320a, and microRNA-423-5p are potential biomarkers for colorectal carcinoma. J Exp Clin Cancer Res 34, 86, 2015. http://dx.doi.org/10.1186/s13046-015-0198-6

Ferreira R, Santos T, Amar A, Gong A, Chen TC, Tahara SM, Giannotta SL, Hofman FM. Argonaute-2 promotes miR18a entry in human brain endothelial cells. J Am Heart Assoc 3, e000968, 2014. http://dx.doi.org/10.1161/ JAHA.114.000968

Garber KB, Visootsak J, Warren ST. Fragile X syndrome. Eur J Hum Genet 16, 666-672, 2008. http://dx.doi. org/10.1038/ejhg.2008.61

Gavrilov K, Saltzman WM. Therapeutic siRNA: principles, challenges, and strategies. Yale J Biol Med 85, 187-200, 2012.

Hanke M, Hoefig K, Merz H, Feller AC, Kausch I, Jocham D, Warnecke JM, Sczakiel G. A robust methodology to study urine microRNA as tumor marker: microRNA-126 and microRNA-182 are related to urinary bladder cancer. Urol Oncol 28, 655-661, 2009. http://dx.doi.org/10.1016/j.urolonc.2009.01.027 
Harfe BD, McManus MT, Mansfield JH, Hornstein E, Tabin CJ. The RNaseIII enzyme Dicer is required for morphogenesis but not patterning of the vertebrate limb. Proc Natl Acad Sci U S A 102, 10898-10903, 2005. http:// dx.doi.org/10.1073/pnas.0504834102

Harris TA, Yamakuchi M, Ferlito M, Mendell JT, Lowenstein CJ. MicroRNA-126 regulates endothelial expression of vascular cell adhesion molecule 1. Proc Natl Acad Sci USA 105, 1516-1521, 2008. http://dx.doi.org/10.1073/ pnas.0707493105

Hatley ME, Patrick DM, Garcia MR, Richardson JA, Bassel-Duby R, van Rooij E, Olson EN. Modulation of K-Rasdependent lung tumorigenesis by MicroRNA-21. Cancer Cell 18, 282-293, 2010. http://dx.doi.org/10.1016/j. ccr.2010.08.013

Hebert SS, Horre K, Nicolai L, Papadopoulou AS, Mandemakers W, Silahtaroglu AN, Kauppinen S, Delacourte A, De Strooper B. Loss of microRNA cluster miR-29a/b-1 in sporadic Alzheimer's disease correlates with increased BACE1/beta-secretase expression. Proc Natl Acad Sci U S A 105, 6415-6420, 2008. http://dx.doi.org/10.1073/ pnas.0710263105

Hornby RJ, Starkey Lewis P, Dear J, Goldring C, Park BK. MicroRNAs as potential circulating biomarkers of druginduced liver injury: key current and future issues for translation to humans. Expert Rev Clin Pharmacol 7, 349-362, 2014. http://dx.doi.org/10.1586/17512433.2014.904201

Hrustincova A, Votavova H, Dostalova Merkerova M. Circulating MicroRNAs: Methodological Aspects in Detection of These Biomarkers.Folia Biologica (Praha) 61, 203-218, 2015.

Hydbring P, Badalian-Very G. Clinical applications of microRNAs. F1000Research 2, 136, 2013. http://dx.doi. org/10.12688/f1000research.2-136.v1

Ishizuka A, Siomi MC,Siomi H. A Drosophila fragile X protein interacts with components of RNAi and ribosomal proteins. Genes Dev 16, 2497-2508, 2002. http://dx.doi.org/10.1101/gad.1022002

Janssen HL, Reesink HW, Lawitz EJ, Zeuzem S, Rodriguez-Torres M, Patel K, van der Meer AJ, Patick AK, Chen A, Zhou Y, Persson R, King BD, Kauppinen S, Levin AA, Hodges MR. Treatment of HCV infection by targeting microRNA. N Engl J Med 368, 1685-1694, 2013. http://dx.doi.org/10.1056/NEJMoa1209026

Ji R, Cheng Y, Yue J, Yang J, Liu X, Chen H, Dean DB, Zhang C. MicroRNA expression signature and antisensemediated depletion reveal an essential role of MicroRNA in vascular neointimal lesion formation. Circ Res 100, 1579-1588, 2007. http://dx.doi.org/10.1161/CIRCRESAHA.106.141986

Ji X, Takahashi R, Hiura Y, Hirokawa G, Fukushima Y, Iwai N. Plasma miR-208 as a biomarker of myocardial injury. Clin Chem 55, 1944-1949, 2009. http://dx.doi.org/10.1373/clinchem.2009.125310

Johnson SM, Grosshans H, Shingara J, Byrom M, Jarvis R, Cheng A, Labourier E, Reinert KL, Brown D, Slack FJ. RAS is regulated by the let-7 microRNA family. Cell 120, 635-647, 2005. http://dx.doi.org/10.1016/j.cell.2005.01.014

Jose AM. Movement of regulatory RNA between animal cells. Genesis 53, 395-416, 2015. http://dx.doi.org/10.1002/ dvg. 22871

Kanellopoulou C, Muljo SA, Kung AL, Ganesan S, Drapkin R, Jenuwein T, Livingston DM, Rajewsky K. Dicerdeficient mouse embryonic stem cells are defective in differentiation and centromeric silencing. Genes Dev 19, 489-501, 2005. http://dx.doi.org/10.1101/gad.1248505

Karolina DS, Tavintharan S, Armugam A, Sepramaniam S, Pek SL, Wong MT, Lim SC, Sum CF, Jeyaseelan K. Circulating miRNA profiles in patients with metabolic syndrome. J Clin Endocrinol Metab 97, E2271-E2276, 2012. http://dx.doi.org/10.1210/jc.2012-1996

Karube Y, Tanaka H, Osada H, Tomida S, Tatematsu Y, Yanagisawa K, Yatabe Y, Takamizawa J, Miyoshi S, Mitsudomi T, Takahashi T. Reduced expression of Dicer associated with poor prognosis in lung cancer patients. Cancer Sci 96, 111-115, 2005. http://dx.doi.org/10.1111/j.1349

Katsuda T, Kosaka N, Ochiya T. The roles of extracellular vesicles in cancer biology: toward the development of novel cancer biomarkers. Proteomics 14, 412-425, 2014. http://dx.doi.org/10.1002/pmic.201300389

Kim HS, Lee KS, Bae HJ, Eun JW, Shen Q, Park SJ, Shin WC, Yang HD, Park M, Park WS, Kang YK, Nam SW. MicroRNA-31 functions as a tumor suppressor by regulating cell cycle and epithelial-mesenchymal transition regulatory proteins in liver cancer. Oncotarget 6, 8089-8102, 2015. http://dx.doi.org/10.18632/oncotarget.3512

Kiriakidou M, Nelson PT, Kouranov A, Fitziev P, Bouyioukos C, Mourelatos Z, Hatzigeorgiou A. A combined computational-experimental approach predicts human microRNA targets. Genes Dev 18, 1165-1178, 2004. http://dx.doi.org/10.1101/gad.1184704

Koldehoff M, Steckel NK, Beelen DW, Elmaagacli AH. Therapeutic application of small interfering RNA directed against bcr-abl transcripts to a patient with imatinib-resistant chronic myeloid leukaemia. Clin Exp Med 7, 47-55, 2007. http://dx.doi.org/10.1007/s10238-007-0125-z 
Kole AJ, Swahari V, Hammond SM, Deshmukh M. miR-29b is activated during neuronal maturation and targets BH3-only genes to restrict apoptosis. Genes Dev 25, 125-130, 2011. http://dx.doi.org/10.1101/gad.1975411

Kosaka N, Iguchi H, Yoshioka Y, Takeshita F, Matsuki Y, Ochiya T. Secretory mechanisms and intercellular transfer of microRNAs in living cells. J Biol Chem 285, 17442-17452, 2010. http://dx.doi.org/10.1074/jbc.M110.107821

Koumangoye RB, Sakwe AM, Goodwin JS, Patel T, Ochieng J. Detachment of breast tumor cells induces rapid secretion of exosomes which subsequently mediate cellularadhesion and spreading. PLoS One 6, e24234, 2011. http://dx.doi.org/10.1371/journal.pone.0024234

Kuehbacher A, Urbich C, Zeiher AM, Dimmeler S. Role of Dicer and Drosha for endothelial microRNA expression and angiogenesis. Circ Res 101, 59-68, 2007. http://dx.doi.org/10.1161/CIRCRESAHA.107.153916

Kumar MS, Erkeland SJ, Pester RE, Chen CY, Ebert MS, Sharp PA, Jacks T. Suppression of non-small cell lung tumor development by the let-7 microRNA family. Proc Natl Acad Sci U S A 105, 3903-3908, 2008. http://dx.doi. org/10.1073/pnas.0712321105

Lagos-Quintana M, Rauhut R, Yalcin A, Meyer J, Lendeckel W, Tuschl T. Identification of tissue-specific microRNAs from mouse. Curr Biol 12, 735-739, 2002. http://dx.doi.org/10.1016/S0960-9822(02)00809-6

Lam JKW, Chow MYT, Zhang Y, Leung SWS. siRNA Versus miRNA as Therapeutics for Gene Silencing. Mol Ther Nucleic Acids 4, e252, 2015. http://dx.doi.org/10.1038/mtna.2015.23

Lee RC, Feinbaum RL, Ambros V. The C. elegans heterochronic gene lin-4 encodes small RNAs with antisense complementarity to lin-14. Cell 75, 843-854, 1993. http://dx.doi.org/10.1016/0092-8674(93)90529-Y

Lee KH, Kim SH, Lee HR, Kim W, Kim DY, Shin JC, Yoo SH, Kim KT. MicroRNA-185 oscillation controls circadian amplitude of mouse Cryptochrome 1 via translational regulation. Mol Biol Cell 24, 2248-2255, 2013. http:// dx.doi.org/10.1091/mbc.E12-12-0849

Li Y, Fan L, Liu S, Liu W, Zhang H, Zhou T, Wu D, Yang P, Shen L, Chen J, Jin Y. The promotion of bone regeneration through positive regulation of angiogenic-osteogenic coupling using microRNA-26a. Biomaterials. 34, 5048-5058, 2013. http://dx.doi.org/10.1016/j.biomaterials.2013.03.052

Li H, Cheng Wu C, Aramayo R, Sachs MS, Harlowa ML. Synaptic vesicles contain small ribonucleic acids (sRNAs) including transfer RNA fragments (trfRNA) and microRNAs (miRNA). Sci Rep 5, 14918, 2015. http://dx.doi. org/10.1038/srep14918

Liang G, Zhu Y, Sun B, Shao Y, Jing A, Wang J, Xiao Z. Assessing the survival of exogenous plant microRNA in mice. Food Sci Nutr 2, 380-388, 2014. http://dx.doi.org/10.1002/fsn3.113

Liu WH, Yeh SH, Lu CC, Yu SL, Chen HY, Lin CY, Chen DS, Chen PJ. MicroRNA-18a prevents estrogen receptoralpha expression, promoting proliferation of hepatocellular carcinoma cells. Gastroenterology 136, 683-693, 2009. http://dx.doi.org/10.1053/j.gastro.2008.10.029

Liu DZ, Tian Y, Ander BP, Xu H, Stamova BS, Zhan X, Turner RJ, Jickling G, Sharp FR. Brain and blood microRNA expression profiling of ischemic stroke, intracerebral hemorrhage, and kainate seizures. J Cereb Blood Flow Metab 30, 92-101, 2010a. http://dx.doi.org/10.1038/jcbfm.2009.186

Liu X, Sempere LF, Ouyang H, Memoli VA, Andrew AS, Luo Y, Demidenko E, Korc M, Shi W, Preis M, Dragnev KH, Li H, Direnzo J, Bak M, Freemantle SJ, Kauppinen S, Dmitrovsky E. MicroRNA-31 functions as an oncogenic microRNA in mouse and human lung cancer cells by repressing specific tumor suppressors. J Clin Invest 120, 1298-309, 2010b. http://dx.doi.org/10.1172/JCI39566

Liu M, Zhi Q, Wang W, Zhang Q, Fang T, Ma Q. Up-regulation of miR-592 correlates with tumor progression and poor prognosis in patients with colorectal cancer. Biomed Pharmacother 69, 214-220, 2015. http://dx.doi. org/10.1016/j.biopha.2014.12.001

Long G, Wang F, Li H, Yin Z, Sandip C, Lou Y, Wang Y, Chen C, Wang DW. Circulating miR-30a, miR-126 and let-7b as biomarker for ischemic stroke in humans. BMC Neurol 13, 178, 2013. http://dx.doi.org/10.1186/1471-2377$13-178$

Lu J, Getz G, Miska EA, Alvarez-Saavedra E, Lamb J, Peck D, Sweet-Cordero A, Ebert BL, Mak RH, Ferrando AA, Downing JR, Jacks T, Horvitz HR, Golub TR. MicroRNA expression profiles classify human cancers. Nature 435, 834-838, 2005. http://dx.doi.org/10.1038/nature03702

Lu J, Guo S, Ebert BL, Zhang H, Peng X, Bosco J, Pretz J, Schlanger R, Wang JY, Mak RH, Dombkowski DM, Preffer FI, Scadden DT, Golub TR. MicroRNA-mediated control of cell fate in megakaryocyte-erythrocyte progenitors. Dev Cell 14, 843-853, 2008. http://dx.doi.org/10.1016/j.devcel.2008.03.012

Luo SS, Ishibashi O, Ishikawa G, Ishikawa T, Katayama A, Mishima T, Takizawa T, Shigihara T, Goto T, Izumi A, Ohkuchi A, Matsubara S, Takeshita T,Takizawa T. Human villous trophoblasts express and secrete placentaspecific microRNAs into maternal circulation via exosomes. Biol Reprod 81, 717-729, 2009. http://dx.doi. org/10.1095/biolreprod.108.075481 
Luo H, Zou J, Dong Z, Zeng Q, Wu D, Liu L. Up-regulated miR-17 promotes cell proliferation, tumour growth and cell cycle progression by targeting the RND3 tumour suppressor gene in colorectal carcinoma. Biochem J 442, 311-321, 2012. http://dx.doi.org/10.1042/BJ20111517

Ma R, Jiang T, Kang X. Circulating microRNAs in cancer: origin, function and application. J Exp Clin Cancer Res 31, 38, 2012. http://dx.doi.org/10.1186/1756-9966-31-38

Mahn R, Heukamp LC, Rogenhofer S, von Ruecker A, Muller SC, Ellinger J. Circulating microRNAs (miRNA) in serum of patients with prostate cancer. Urology 77, 1265.e9-16, 2011. http://dx.doi.org/10.1016/j.urology.2011.01.020

Makeyev EV, Zhang J, Carrasco MA, Maniatis T. The MicroRNA miR-124 promotes neuronal differentiation by triggering brain-specific alternative pre-mRNAsplicing. Mol Cell 27, 435-448, 2007. http://dx.doi.org/10.1016/j. molcel.2007.07.015

Mitchell PS, Parkin RK, Kroh EM, Fritz BR, Wyman SK, Pogosova-Agadjanyan EL, Peterson A, Noteboom J, O`Briant KC, Allen A, Lin DW, Urban N, Drescher CW, Knudsen BS, Stirewalt DL, Gentleman R, Vessella RL, Nelson PS, Martin DB, Tewari M. Circulating microRNAs as stable blood-based markers for cancer detection. Proc Natl Acad Sci U S A 105, 10513-10518, 2008. http://dx.doi.org/10.1073/pnas.0804549105

Mogilyansky E, Rigoutsos I. The miR-17/92 cluster: a comprehensive update on its genomics, genetics, functions and increasingly important and numerous roles in health and disease. Cell Death Differ 20, 1603-1614, 2013. http://dx.doi.org/10.1038/cdd.2013.125

Mulcahy LA, Pink RC, Carter DR. Routes and mechanisms of extracellular vesicle uptake. J Extracell Vesicles 3, eCollection, 2014. http://dx.doi.org/10.3402/jev.v3.24641

Murata K, Furu M, Yoshitomi H, Ishikawa M, Shibuya H, Hashimoto M, Imura Y, Fujii T, Ito H, Mimori T, Matsuda S. Comprehensive microRNA Analysis Identifies miR-24 and miR-125a-5p as Plasma Biomarkers for Rheumatoid Arthritis. PLoS One 8, e69118, 2013. http://dx.doi.org/10.1371/journal.pone.0069118

Nagel R, Clijsters L, Agami R. The miRNA-192/194 cluster regulates the Period gene family and the circadian clock. FEBS J 276, 5447-5455, 2009. http://dx.doi.org/10.1111/j.1742-4658.2009.07229.x

Nielsen LB, Wang C, Sorensen K, Bang-Berthelsen CH, Hansen L, Andersen ML, Hougaard P, Juul A, Zhang CY, Pociot F, Mortensen HB. Circulating levels of microRNA from children with newly diagnosed type 1 diabetes and healthy controls: evidence that miR-25 associates to residual beta-cell function and glycaemic control during disease progression. Exp Diabetes Res 2012, 896362, 2012. http://dx.doi.org/10.1155/2012/896362

Ohshima K, Inoue K, Fujiwara A, Hatakeyama K, Kanto K, Watanabe Y, Muramatsu K, Fukuda Y, Ogura S, Yamaguchi K, Mochizuki T. Let-7 microRNA family is selectively secreted into the extracellular environment via exosomes in a metastatic gastric cancer cell line. PLoS One 5, e13247, 2010. http://dx.doi.org/10.1371/journal. pone.0013247

Pang J, Xiong H, Yang H, Ou Y, Xu Y, Huang Q, Lai L, Chen S, Zhang Z, Cai Y, Zheng Y. Circulating miR-34a levels correlate with age-related hearing loss in mice and humans. Exp Gerontol 76, 58-67, 2016. http://dx.doi. org/10.1016/j.exger.2016.01.009

Park NJ, Zhou H, Elashoff D, Henson BS, Kastratovic DA, Abemayor E, Wong DT. Salivary microRNA: discovery, characterization, and clinical utility for oral cancer detection. Clin Cancer Res 15, 5473-5477, 2009. http:// dx.doi.org/10.1158/1078-0432.CCR-09-0736

Pedersen I, David M. MicroRNAs in the immune response. Cytokine 43, 391-394, 2008. http://dx.doi.org/10.1016/j. cyto.2008.07.016

Persengiev S, Kondova I, Otting N, Koeppen AH, Bontrop RE. Genome-wide analysis of miRNA expression reveals a potential role for miR-144 in brain aging and spinocerebell arataxia pathogenesis. Neurobiol Aging 32, 2316. e17-27, 2011. http://dx.doi.org/10.1016/j.neurobiolaging.2010.03.014

Pigati L, Yaddanapudi SC, Iyengar R, Kim DJ, Hearn SA, Danforth D, Hastings ML, Duelli DM. Selective release of microRNA species from normal and malignant mammary epithelial cells. PLoS One 5, e13515, 2010. http:// dx.doi.org/10.1371/journal.pone.0013515

Poliseno L, Tuccoli A, Mariani L, Evangelista M, Citti L, Woods K, Mercatanti A, Hammond S, Rainaldi G. MicroRNAs modulate the angiogenic properties of HUVECs. Blood 108, 3068-3071, 2006. http://dx.doi.org/10.1182/ blood-2006-01-012369

Poy MN, Spranger M, Stoffel M. microRNAs and the regulation of glucose and lipid metabolism. Diabetes Obes Metab 9, 67-73, 2007. http://dx.doi.org/10.1111/j.1463-1326.2007.00775.x

Pritchard CC, Kroh E, Wood B, Arroyo JD, Dougherty KJ, Miyaji MM, Tait JF, Tewari M. Blood cell origin of circulating microRNAs: a cautionary note for cancer biomarker studies. Cancer Prev Res (Phila) 5, 492-497, 2012. http://dx.doi.org/10.1158/1940-6207.CAPR-11-0370 
Redis RS, Calin S, Yang Y, You MJ, Calin GA. Cell-to-cell miRNA transfer: from body homeostasis to therapy. Pharmacol Ther 136, 169-174, 2012. http://dx.doi.org/10.1016/j.pharmthera.2012.08.003

Reid G, Kirschner MB, van Zandwijk N. Circulating microRNAs: Association with disease and potential use as biomarkers. Crit Rev Oncol Hematol 80, 193-208, 2011. http://dx.doi.org/10.1016/j.critrevonc.2010.11.004

Reinhart BJ, Slack FJ, Basson M, Pasquinelli AE, Bettinger JC, Rougvie AE, Horvitz HR, Ruvkun G. The 21-nucleotide let-7 RNA regulates developmental timing in Caenorhabditis elegans. Nature 403, 901-906, 2000. http:// dx.doi.org/10.1038/35002607

Roese-Koerner B, Stappert L, Koch P, Brustle O, Borghese L. Pluripotent stem cell-derived somatic stem cells as tool to study the role of microRNAs in early human neural development. Curr Mol Med 13, 707-722, 2013. http:// dx.doi.org/10.2174/1566524011313050003

Sarkar J, Gou D, Turaka P, Viktorova E, Ramchandran R, Raj JU. MicroRNA-21 plays a role in hypoxia-mediated pulmonary artery smooth muscle cell proliferation and migration. Am J Physiol Lung Cell Mol Physiol 299, L861-871, 2010. http://dx.doi.org/10.1152/ajplung.00201.2010

Sayed D, Hong C, Chen IY, Lypowy J, Abdellatif M. MicroRNAs play an essential role in the development of cardiac hypertrophy. Circ Res 100, 416-424, 2007. http://dx.doi.org/10.1161/01.RES.0000257913.42552.23

Shende VR, Goldrick MM, Ramani S, Earnest DJ. Expression and Rhythmic Modulation of Circulating MicroRNAs Targeting the Clock Gene Bmal1 in Mice. PLoS One 6, e22586, 2011. http://dx.doi.org/10.1371/journal. pone.0022586

Shi B, Sepp-Lorenzino L, Prisco M, Linsley P, deAngelis T, Baserga R. Micro RNA 145 targets the insulin receptor substrate-1 and inhibits the growth of colon cancer cells. J Biol Chem 282, 32582-32590, 2007. http://dx.doi. org/10.1074/jbc.M702806200

Shi XB, Xue L, Ma AH, Tepper CG, Gandour-Edwards R, Kung HJ, deVere White RW. Tumor suppressive miR-124 targets androgen receptor and inhibits proliferation of prostate cancer cells. Oncogene 32, 4130-4138, 2013. http://dx.doi.org/10.1038/onc.2012.425

Schratt GM, Tuebing F, Nigh EA, Kane CG, Sabatini ME, Kiebler M, Greenberg ME. A brain-specific microRNA regulates dendritic spine development. Nature 439, 283-289, 2006. http://dx.doi.org/10.1038/nature04367

Squadrito ML, Baer C, Burdet F, Maderna C, Gilfillan GD, Lyle R, Ibberson M, De Palma M. Endogenous RNAs modulate microRNA sorting to exosomes and transfer to acceptor cells. Cell Rep 8, 1432-4146, 2014. http:// dx.doi.org/10.1016/j.celrep.2014.07.035

Su YW, Chen X, Jiang ZZ, Wang T, Wang C, Zhang Y, Wen J, Xue M, Zhu D, Zhang Y, Su YJ, Xing TY, Zhang CY, Zhang LY. A panel of serum microRNAs as specific biomarkers for diagnosis of compound- and herb-induced liver injury in rats. PLoS One 7, e37395, 2012. http://dx.doi.org/10.1371/journal.pone.0037395

Sun D, Yu F, Ma Y, Zhao R, Chen X, Zhu J, Zhang CY, Chen J, Zhang J. MicroRNA-31 activates the RAS pathway and functions as an oncogenic MicroRNA in human colorectal cancer by repressing RAS p21 GTPase activating protein 1 (RASA1). J Biol Chem 288, 9508-9518, 2013. http://dx.doi.org/10.1074/jbc.M112.367763

Sun X, Yang Z, Zhang Y, He J, Wang F, Su P, Han J, Song Z, Fei Y. Prognostic implications of tissue and serum levels of microRNA-128 in human prostate cancer. Int J Clin Exp Pathol 8, 8394-8401, 2015.

Silvestre JS, Mallat Z, Tedgui A, Levy BI. Post-ischaemic neovascularization and inflammation. Cardiovasc Res 78, 242-249. 2008. http://dx.doi.org/10.1093/cvr/cvn027.

Szafranski K, Abraham KJ, Mekhail K. Non-coding RNA in neural function, disease, and aging. Front Genet 6, 87, eCollection 2015. http://dx.doi.org/10.3389/fgene.2015.00087

Tang P, Xiong Q, Ge W, Zhang L. The role of microRNAs in osteoclasts and osteoporosis. RNA Biol 11, 1355-1363, 2014. http://dx.doi.org/10.1080/15476286.2014.996462

Tang R, Yang C, Ma X, Wang Y, Luo D, Huang C, Xu Z, Liu P, Yang L. MiR-let-7a inhibits cell proliferation, migration, and invasion by down-regulating PKM2 in gastric cancer. Oncotarget, 7, 5972-5984. 2016. http://dx.doi. org/10.18632/oncotarget.6821

Thomson JM, Newman M, Parker JS, Morin-Kensicki EM, Wright T, Hammond SM. Extensive post-transcriptional regulation of microRNAs and its implications for cancer. Genes Dev 20, 2202-2207, 2006. http://dx.doi. org $/ 10.1101 /$ gad.1444406

Tian Y, Liu Y, Wang T, Zhou N, Kong J, Chen L, Snitow M, Morley M, Li D, Petrenko N, Zhou S, Lu M, Gao E, Koch WJ, Stewart KM, Morrisey EE. A microRNA-hippo pathway that promotes cardiomyocyte proliferation and cardiac regeneration in mice. Sci Transl Med 7, 279ra38, 2015. http://dx.doi.org/10.1126/scitranslmed.3010841

Title AC, Denzler R, Stoffel M. Uptake and Function Studies of Maternal Milk-derived MicroRNAs. J Biol Chem 290, 23680-23691, 2015. http://dx.doi.org/10.1074/jbc.M115.676734 
Toiyama Y, Takahashi M, Hur K, Nagasaka T, Tanaka K, Inoue Y, Kusunoki M, Boland CR, Goel A. Serum miR-21 as a diagnostic and prognostic biomarker in colorectal cancer. J Natl Cancer Inst 105, 849-859, 2013. http:// dx.doi.org/10.1093/jnci/djt101

Turchinovich A, Weiz L, Langheinz A, Burwinkel B. Characterization of extracellular circulating microRNA. Nucleic Acids Res 39, 7223-7233, 2011. http://dx.doi.org/10.1093/nar/gkr254

Valeri N, Gasparini P, Braconi C, Paone A, Lovat F, Fabbri M, Sumani KM, Alder H, Amadori D, Patel T, Nuovo GJ, Fishel R, Croce CM. MicroRNA-21 induces resistance to 5-fluorouracil by down-regulating human DNA MutS homolog 2 (hMSH2). Proc Natl Acad Sci U S A 107, 21098-21103, 2010. http://dx.doi.org/10.1073/ pnas. 1015541107

van Rooij E, Sutherland LB, Liu N, Williams AH, McAnally J, Gerard RD, Richardson JA, Olson EN. A signature pattern of stress-responsive microRNAs that can evoke cardiac hypertrophy and heart failure. Proc Natl Acad Sci U S A 103, 18255-18260, 2006. http://dx.doi.org/10.1073/pnas.0608791103

van Rooij E, Sutherland LB, Qi X, Richardson JA, Hill J, Olson EN. Control of stress-dependent cardiac growth and gene expression by a microRNA. Science 316, 575-579, 2007. http://dx.doi.org/10.1126/science.1139089

van Rooij E, Olson EN. Searching for miR-acles in cardiac fibrosis. Circ Res 104, 138-140, 2009. http://dx.doi. org/10.1161/CIRCRESAHA.108.192492

Vickers KC, Palmisano BT, Shoucri BM, Shamburek RD, Remaley AT. MicroRNAs are transported in plasma and delivered to recipient cells by high-density lipoproteins: Nat Cell Biol 13, 423-433, 2011. http://dx.doi. org/10.1038/ncb2210

Wang K, Zhang S, Marzolf B, Troisch P, Brightman A, Hu Z, Hood LE, Galas DJ. Circulating microRNAs, potential biomarkers for drug-induced liver injury. Proc Natl Acad Sci U S A 106, 4402-4407, 2009a. http://dx.doi. org/10.1073/pnas.0813371106

Wang CJ, Zhou ZG, Wang L, Yang L, Zhou B, Gu J, Chen HY, Sun XF. Clinicopathological significance of microRNA-31, -143 and -145 expression in colorectal cancer. Dis Markers 26, 27-34, 2009b. http://dx.doi. org/10.1155/2009/921907

Wang K, Zhang S, Weber J, Baxter D, Galas DJ. Export of microRNAs and microRNA-protective protein by mammalian cells. Nucleic Acids Res 38, 7248-7259, 2010a. http://dx.doi.org/10.1093/nar/gkq601

Wang CJ, Stratmann J, Zhou ZG, Sun XF. Suppression of microRNA-31 increases sensitivity to 5-FU at an early stage, and affects cell migration and invasion in HCT-116 colon cancer cells. BMC Cancer 10, 616, 2010b. http:// dx.doi.org/10.1186/1471-2407-10-616

Wang B, Zhang Q. The expression and clinical significance of circulating microRNA-21 in serum of five solid tumors. J Cancer Res Clin Oncol 138, 1659-1666, 2012. http://dx.doi.org/10.1007/s00432-012-1244-9

Wang Q, Huang Z, Ni S, Xiao X, Xu Q, Wang L, Huang D, Tan C, Scheng W, Du X. Plasma miR-601 and miR-760 Are Novel Biomarkers for the Early Detection of Colorectal Cancer. PLoS One 7, e44398, 2012a. http://dx.doi. org/10.1371/journal.pone.0044398

Wang H, Peng W, Ouyang X, Li W, Dai Y. Circulating microRNAs as candidate biomarkers in patients with systemic lupus erythematosus. Transl Res 160, 198-206, 2012b. http://dx.doi.org/10.1016/j.trsl.2012.04.002

Wang YC, Li Y, Wang XY, Zhang D, Zhang H, Wu Q, He YQ, Wang JY, Zhang L, Xia H, Yan J, Li X, Ying H. Circulating miR-130b mediates metabolic crosstalk between fat and muscle in overweight/obesity. Diabetologia 56, 2275-2285, 2013. http://dx.doi.org/10.1007/s00125-013-2996-8

Wang F, Long G, Zhao C, Li H, Chaugai S, Wang Y, Chen C, Wang DW. Atherosclerosis-Related Circulating miRNAs as Novel and Sensitive Predictors for Acute Myocardial Infarction. PLoS One 9, e105734, 2014. http://dx.doi. org/10.1371/journal.pone.0105734

Welch C, Chen Y, Stallings RL. MicroRNA-34a functions as a potential tumor suppressor by inducing apoptosis in neuroblastoma cells. Oncogene 26, 5017-5022, 2007. http://dx.doi.org/10.1038/sj.onc.1210293

Wightman B, Ha I, Ruvkun G. Posttranscriptional regulation of the heterochronic gene Lin-14 by Lin-4 mediates temporal pattern-formation in C.elegans. Cell 75, 855-862, 1993. http://dx.doi.org/10.1016/00928674(93)90530-4

Witwer KW, Hirschi KD. Transfer and functional consequences of dietary microRNAs in vertebrates: concepts in search of corroboration: negative results challenge the hypothesis that dietary xenomiRs cross the gut and regulate genes in ingesting vertebrates, but important questions persist. Bioessays 36, 394-406, 2014. http:// dx.doi.org/10.1002/bies.201300150

Wu CW, Dong YJ, Liang QY, He XQ, Ng SS, Chan FK, Sung JJ, Yu J. MicroRNA-18a attenuates DNA damage repair through suppressing the expression of ataxia telangiectasia mutated in colorectal cancer. PLoS One 8, e57036, 2013. http://dx.doi.org/10.1371/journal.pone.0057036 
Wulfken LM, Moritz R, Ohlmann C, Holdenrieder S, Jung V, Becker F, Herrmann E, Walgenbach-Brunagel G, von Ruecker A, Muller SC, Ellinger J. MicroRNAs in renal cell carcinoma: diagnostic implications of serum miR1233 levels. PLoS One 6, e25787, 2011. http://dx.doi.org/10.1371/journal.pone.0025787

Xiong J, Yu D, Wei N, Fu H, Cai T, Huang Y, Wu C, Zheng X, Du Q, Lin D, Liang Z. An estrogen receptor alpha suppressor, microRNA-22, is downregulated in estrogen receptor alpha-positive human breast cancer cell lines and clinical samples. FEBS J 277, 1684-1694, 2010. http://dx.doi.org/10.1111/j.1742-4658.2010.07594.x

Xiong B, Cheng Y, Ma L, Zhang C. MiR-21 regulates biological behavior through the PTEN/PI-3 K/Akt signaling pathway in human colorectal cancer cells. Int J Oncol 42, 219-228, 2013. http://dx doi/10.3892/ijo.2012.1707.

Xu RS, Wu XD, Zhang SQ, Li CF, Yang L, Li DD, Zhang BG, Zhang Y, Jin JP, Zhang B. The tumor suppressor gene RhoBTB1 is a novel target of miR-31 in human colon cancer. Int J Oncol 42, 676-682, 2013. http://dx doi/10.3892/ijo.2012.1746

Xu L, Li M, Wang M, Yan D, Feng G, An G. The expression of microRNA-375 in plasma and tissue is matched in human colorectal cancer. BMC Cancer 14, 714, 2014. http://dx.doi.org/10.1186/1471-2407-14-714

Yamada H, Itoh M, Hiratsuka I, Hashimoto S. Circulating microRNAs in autoimmune thyroid diseases. Clin Endocrinol (Oxf) 81, 276-281, 2014. http://dx.doi.org/10.1111/cen.12432

Yang B, Lin H, Xiao J, Lu Y, Luo X, Li B, Zhang Y, Xu C, Bai Y, Wang H, Chen G, Wang Z. The muscle-specific microRNA miR-1 regulates cardiac arrhythmogenic potential by targeting GJA1 and KCNJ2. Nat Med 13, 486-491, 2007. http://dx.doi.org/10.1038/nm1569

Yang Z, Chen H, Si H, Li X, Ding X, Sheng Q, Chen P, Zhang H. Serum miR-23a, a potential biomarker for diagnosis of pre-diabetes and type 2 diabetes. Acta Diabetol 51, 823-831, 2014. http://dx.doi.org/10.1007/s00592-014017-8

Yang Y, Chang S, Zhao Z, Hou NI, He K, Wang X, Gao L, Wang L, Cai D, Guo BO, Tong D, Song T, Huang C. MicroRNA-214 suppresses the proliferation of human hepatocellular carcinoma cells by targeting E2F3. Oncol Lett 10, 3779-3784, 2015. http://dx.doi.org/10.3892/ol.2015.3745

Ye W, Lv Q, Wong C-KA, Hu S, Fu C, Hua Z, Cai G, Li G, Yang BB, Zhang Y. The Effect of Central Loops in miRNA:MRE Duplexes on the Efficiency of miRNA-Mediated Gene Regulation. PLoS One 3, e1719, 2008. http://dx.doi.org/10.1371/journal.pone.0001719

Zampetaki A, Kiechl S, Drozdov I, Willeit P, Mayr U, Prokopi M, Mayr A, Weger S, Oberhollenzer F, Bonora E, Shah A, Willeit J, Mayr M. Plasma microRNA profiling reveals loss of endothelial miR-126 and other microRNAs in type 2 diabetes. Circ Res 107, 810-817, 2010. http://dx.doi.org/10.1161/CIRCRESAHA.110.226357

Zampetaki A, Willeit P, Drozdov I, Kiechl S, Mayr M. Profiling of circulating microRNAs: from single biomarkers to re-wired networks. Cardiovasc Res 93, 555-562, 2012. http://dx.doi.org/10.1093/cvr/cvr266

Zeng W, Tu Y, Zhu Y, Wang Z, Li C, Lao L, Wu G. Predictive power of circulating miRNAs in detecting colorectal cancer. Tumour Biol 36, 2559-2567, 2015. http://dx.doi.org/10.1007/s13277-014-2872-2

Zhang B, Wang Q, Pan X. MicroRNA and Their Regulatory Roles in Animals and Plants. J Cell Physiol 210, 279-289, 2007a. http://dx.doi.org/10.1002/jcp.20869

Zhang B, Pan X, Cobb GP, Anderson TA. microRNAs as oncogenes and tumor suppressors. Dev Biol 302, 1-12, 2007b. http://dx.doi.org/10.1016/j.ydbio.2006.08.028

Zhang C. MicroRNAs: role in cardiovascular biology and disease. Clin Sci (Lond) 114, 699-706, 2008. http://dx.doi. org/10.1042/CS20070211

Zhang Z, Li Z, Gao C, Chen P, Chen J, Liu W, Xiao S, Lu H. miR-21 plays a pivotal role in gastric cancer pathogenesis and progression. Lab Invest 88, 1358-1366, 2008. http://dx.doi.org/10.1038/labinvest.2008.94

Zhang L, Hou D, Chen X, Li D, Zhu L, Zhang Y, Li J, Bian Z, Liang X, Cai X, Yin Y, Wang C, Zhang T, Zhu D, Zhang D, Xu J, Chen Q, Ba Y, Liu J, Wang Q, Chen J, Wang J, Wang M, Zhang Q, Zhang J, Zen K, Zhang CY. Exogenous plant MIR168a specifically targets mammalian LDLRAP1: evidence of cross-kingdom regulation by microRNA. Cell Res 22, 107-126, 2012. http://dx.doi.org/10.1038/cr.2011.174

Zheng L, Xu CC, Chen WD, Shen WL, Ruan CC, Zhu LM, Zhu DL, Gao PJ. MicroRNA-155 regulates angiotensin II type 1 receptor expression and phenotypic differentiation in vascular adventitial fibroblasts. Biochem Biophys Res Commun 400, 483-488, 2010. http://dx.doi.org/10.1016/j.bbrc.2010.08.067

Zong L, Zhu Y, Liang R, Zhao HB. Gap junction mediated miRNA intercellular transfer and gene regulation: A novel mechanism for intercellulargenetic communication. Sci Rep 6, 19884, 2016. http://dx.doi.org/10.1038/ srep19884

Zuckerman JE, Davis ME. Clinical experiences with systemically administered siRNA-based therapeutics in cancer. Nat Rev Drug Discov 14, 843-856, 2015. http://dx.doi.org/10.1038/nrd4685 